\title{
"ALARA in radioactive waste management" Summary and recommendations of the 11th European ALARA Network Workshop
}

\author{
P. SHAW ${ }^{1}$, P. CROÜAIL ${ }^{2}$, F. DROUET ${ }^{2}$
}

(Manuscript received 15 September 2008, accepted 17 September 2008)

ABSTRACT The 11th European ALARA Network (EAN) workshop on "ALARA in radioactive waste management" took place in Athens (Greece) in April 2008. The aim of that workshop was to focus on the implementation of the ALARA ${ }^{3}$ principle with regard to occupational and public exposures arising from the management of radioactive waste in all sectors (nuclear, medical, industrial, etc.). This workshop consisted of invited oral presentations, which highlighted the main issues, and half of the programme was devoted to discussions within working groups on specific topics. Individual presentations (papers and slides) are available to download from the EAN website (http://www.eu-alara.net). Based on report backs from the groups and discussions with all the participants, five formal recommendations have been formulated. These recommendations, addressed to international organisations (International Atomic Energy Agency, European Commission, Nuclear Energy Agency), national authorities, national and local stakeholders and to EAN itself, deal with the following themes: international guidance on ALARA in radioactive waste management, harmonisation issues at the international level, ALARA approach in non-nuclear waste management, "broader approach" in the radioactive waste management process, stakeholder involvement. The objective of this paper is to present the main conclusions and the five recommendations produced during the workshop.

Keywords: ALARA / waste management / recommendations

RÉSUMÉ «L'application du principe ALARA dans la gestion des déchets radioactifs » Résumé et recommandations du $11^{\mathrm{e}}$ séminaire du réseau ALARA européen (EAN).

Le $11^{\mathrm{e}}$ séminaire du réseau ALARA européen sur « L'application du principe ALARA dans la gestion des déchets radioactifs » s'est déroulé à Athènes (Grèce) en avril 2008. Le but de ce séminaire était de discuter de la mise en œuvre du principe d'optimisation de la radioprotection (principe ALARA ${ }^{3}$ ) pour les expositions professionnelles et du public lors de la gestion des déchets radioactifs dans l'ensemble des secteurs concernés (nucléaire, médical, industrie, etc.). La moitié du programme était consacrée à des présentations orales invitées, destinées à souligner les problématiques principales, et l'autre moitié à des discussions en groupes de travail sur différentes thématiques. Les présentations orales (articles et diapositives)

\footnotetext{
HPA, Radiation Protection Division, Occupational Services Dept., Hospital Lane, Cookridge, Leeds LS 16 6RW, UK.

CEPN, 28 rue de la Redoute, 92260 Fontenay-aux-Roses, France.
}

As Low As Reasonably Achievable - Aussi bas que raisonnablement possible. 
peuvent être téléchargées depuis le site Internet du réseau EAN (http://www. eu-alara.net). Sur la base de la présentation des travaux de ces groupes et des discussions avec l'ensemble des participants, cinq recommandations ont été formulées. Ces recommandations, destinées aux organisations internationales (Agence internationale de l'énergie atomique, Commission européenne, Agence pour l'énergie nucléaire), aux autorités nationales, à des partie prenantes nationales et locales et au réseau EAN lui-même, abordent les thèmes suivants : le besoin de guides internationaux pour l'application de la démarche ALARA à la gestion des déchets radioactifs, les questions d'harmonisation au niveau international, la mise en ouvre de la démarche ALARA dans la gestion des déchets non nucléaires, «l'approche intégrée » dans le processus de gestion des déchets, l'implication des parties prenantes. L'objectif de cet article est de présenter les principales conclusions et les cinq recommandations issues de ce séminaire.

\section{Workshop objectives and programme}

The aim of the 11th European ALARA Network (EAN) workshop was to discuss the implementation of the ALARA principle with regard to occupational and public exposures arising from the management of radioactive waste. This includes waste from the nuclear fuel cycle, medical, NORM ${ }^{4}$, industrial, educational and research sectors. There were 62 participants from 15 different European countries representing these different sectors. In addressing radioactive waste management, the workshop aimed to consider topics such as re-use and recycling, interim and decay storage, clearance levels and discharges to the environment, as well as final disposal to a repository.

As with previous workshops, half the programme time was devoted to presentations, and half to Working Group (WG) discussions and their findings. Participants had the opportunity to consider the findings of each WG, contribute to discussions, and formulate the final recommendations of the Workshop.

In total, there were 20 oral presentations, arranged under the following sessions:

- introduction and setting the scene;

- stakeholder involvement and decision-making;

- application of the ALARA principle;

- practical experience from the non-nuclear sectors; and

- practical experience from the nuclear sector.

Two afternoon sessions were set aside for WG discussions, based on the following topic areas:

- Dealing with doses - how to take account of different dose distributions, worker and public doses, doses over long timescales, etc?

\footnotetext{
4 Naturally Occurring Radioactive Material.
} 
- How should ALARA be applied and implemented in the areas of re-use and recycling of radioactive residues?

- How should ALARA be applied and implemented in the area of disposal of radioactive waste?

- Should different strategies be applied to the different sectors and what should these differences be?

- What are the main criteria that should be used for decision-making in the management of radioactive waste?

The reports from the groups were presented and discussed on the final day, and are the basis for the findings and recommendations from the workshop.

A number of significant themes and issues emerged, and these are described below. The individual presentations (papers and slides) are available to download from the EAN website (http://www.eu-alara.net).

\section{Themes and issues arising}

The introductory session considered the international and national approaches to radioactive waste management (RWM). In terms of the former, the new ICRP recommendations (Publication 103) were evoked. The impacts of these recommendations are still being considered in the current revisions to the EU and IAEA Basic Safety Standards. In terms of RWM, all three of the new ICRP exposure situations (planned, existing and emergency) are relevant, and indeed may apply sequentially over the extended period of time envisaged for certain disposal operations (Janssens et al., 2008; Baekelandt and Louvat, 2008).

It is widely agreed that the management of radioactive waste has to be considered an integral part of a practice when applying the principles of justification and optimisation (Janssens et al., 2008; Baekelandt and Louvat, 2008). However, it was clear from the workshop that significant quantities of waste from historical sources already exist, and that these have to be safely managed now and in the future (Howett, 2008). Furthermore, there is an obligation on National Authorities to provide the necessary strategies and facilities to effectively manage waste from both historical and ongoing (justified) operations (Vallet and Bodenez, 2008). It also needs to be ensured, especially in relation to NORM waste, that there is effective communication and co-operation between waste producers and waste recipients, and the regulatory authorities (Gellermann et al., 2008).

Stakeholder involvement has been a theme in many previous EAN workshops, and it would seem to be especially relevant to RWM. The theme has clearly 
continued to develop, and in this workshop a number of examples of Public and Stakeholder Engagement (PSE) were presented. A number of issues emerged, including:

- the objectives and scope of such engagements need to be clearly defined and understood by the different stakeholders (Warren and Morley, 2008; Schieber et al., 2008; De Preter, 2008);

- it is better to provide stakeholders with options to consider, rather than decisions to accept (Warren and Morley, 2008);

- involvement and engagement do not (and should not) be expected to automatically produce agreement or even acceptance. Nor do such exercises simplify the decision-making process; (Warren and Morley, 2008; Schieber et al., 2008); and

- workers are key stakeholders, often likely to receive much higher doses than the public, and need to also be involved in order to favour the common acceptability and the quality of the radioactive waste management process (Vaillant and Drouet, 2008).

The third session dealt with the application of the ALARA principle to the RWM process. This, and the subsequent working group discussions, demonstrated that the interface between ALARA and RWM is complicated, and it is not always clear how it should be applied to issues such as re-use and recycling (Vaillant and Drouet, 2008), decontamination and clearance (Feinhals, 2008), liquid and gaseous discharges, and the disposal of solid waste in repositories (Kunze and Feinhals, 2008; Hefner et al., 2008). The situation is further complicated by the existence of other waste management principles such as Best Available Technique, and Best Practical Means (Morley et al., 2008). There is still only limited consensus on reference levels, for example in terms of activity concentrations for clearance purposes, and the focus on complying with numerical values can often distract from the overall requirement to optimise (Feinhals, 2008).

The third session also highlighted the difficulties associated with considering collective doses, especially where individual doses are low (Morley et al., 2008). As highlighted in the 10th EAN workshop (Croüail et al., 2007), there has been a progressive move away from quantitative techniques such as cost-benefit analysis, and ICRP now recommends a judgemental approach to the issue. The Commission does indicate that less weight should be given to very low doses: the ICRP publication 101 proposes general principles, but there is still a need for detailed practical guidance. In practice, this has left something of a vacuum in the decisionmaking process, especially for those RWM operations that involve very substantial investment (Morley et al., 2008). 
The last two sessions provided an interesting comparison between the nuclear fuel cycle and other sectors. For the latter, discharges to the environment are a key issue, especially for medical and research applications using unsealed radioactive materials (Vogiatzi et al., 2008; Södermann and Hellström, 2008). Doses to the public have often been assessed by models, which have tended to overestimate doses. More detailed studies involving environmental measurements and sampling are required in order to estimate doses with sufficient accuracy for optimisation purposes (McDonnell, 2008a). Even then, the impression is that disposal is governed by the options available, rather than what is best (Södermann and Hellström, 2008; McDonnell, 2008b).

In the nuclear sector, ALARA culture and procedures are much more mature, and good examples of optimisation of worker doses in RWM operations were presented (Savidou et al, 2008; Hansson et al., 2008; Hoffmann et al., 2008). These highlighted that a range of protection options can be effective and other sectors can usefully learn from this experience. Despite the growing acknowledgement that sectors such as NORM do have substantial RWM issues, the nuclear sector still has unrivalled technical and societal problems to resolve in this area. These are too complex to be resolved at this workshop - however, one message to emerge was the importance of considering the process of RWM in its totality - waste exists, and no RWM option is without hazards and risks. Rather, it is better to remind ourselves that waste management involves the safe stewardship of radioactivity, which is surely consistent with the ALARA principle.

\section{Workshop conclusions and recommendations}

Each WG produced conclusions and recommendations, and presented these to participants on the final day of the workshop. The output of the WG was collated and discussed within the participants to formulate the final recommendations as listed below.

\section{Recommendation 1: International guidance on ALARA in radioactive waste management (RWM)}

Although optimisation is seen as a key requirement in RWM, how the ALARA principle should be applied to different stages of the RWM process is often unclear. It is recommended that international bodies (EC, IAEA and NEA) produce guidance to help clarify the interface between the ALARA principle and the various waste management concepts and processes, in particular:

- re-use and recycling;

- dilute and disperse versus concentrate and contain;

- waste treatment and disposal; 
- deriving and using generic and specific clearance levels;

- other waste management principles such as Best Available Technique and Best Practicable Means.

The exchange of practical experience in the field of RWM is especially valuable it helps clarify how principles are implemented in practice, and can save considerable time and effort. It is recommended that international guidance should also include practical examples and experience of the application of ALARA to radioactive waste management. In particular, examples of the following are required:

- re-use and recycling of waste from different sectors;

- the management of hospital waste;

- the management of NORM waste;

- deriving and using specific clearance levels.

EAN and other networks, such as RECAN, are dedicated to the exchange of practical experience, and international bodies should utilise such networks to facilitate the collection of practical RWM examples.

\section{Recommendation 2: Harmonisation issues}

There is a balance between adopting an internationally harmonised approach, and retaining national flexibility for dealing with local issues. The workshop identified that different approaches and requirements should at least aim to be coherent, and the following specific recommendations were made:

- the EC is currently reviewing the difference between their generic clearance levels and those of the IAEA. It is accepted that national authorities may wish to derive specific clearance levels above the recommended generic values; however it is recommended (to national authorities) that the process for establishing such levels is transparent, and that any differences between generic international levels and specific national levels are clearly explained. The practical implications associated with different clearance levels should also be understood. For example, national regulations may need to include statements about cross-border transport, as well as any restrictions on re-using or recycling materials from other countries that have a different approach toward clearance;

- it is noted that some terms are used with different meanings, for example 'disposal' sometimes is understood to include discharges to the environment, sometimes it is not; 'nuclear facility' sometimes refers to a nuclear power plant and sometimes to nuclear fuel cycle facilities or even a facility involving any radioactive material. It is recommended that international organisations, including the EAN, promote the use of a standardised vocabulary. 


\section{Recommendation 3: ALARA and non-nuclear waste management}

The use of conservative models to assess the impact of discharges from research and medical establishments can overestimate doses to members of the public. It is recommended that Research Institutes (and Technical Support Organisations of National Authorities, as appropriate) conduct studies to acquire more realistic models and data, and that international bodies (EC, IAEA) aim to sponsor or support this work, where possible.

These studies should involve suitable monitoring, sampling and analysis so as to better establish the transfer of radionuclides through the environment, and the collection of realistic habit data to help estimate the resulting doses to persons from different exposure pathways.

\section{Recommendation 4: The "broader approach"}

To help clarify the decision-making process, it is useful to assess the totality of the waste management process - including operations such as recycling, transport, storage, treatment, and disposal/release. This should ideally include a consideration of radiological and non-radiological risks, and should consider the inter-dependencies between the different parts of the process.

Large operators should be encouraged to undertake such an assessment themselves. However, in many circumstances, National Authorities may need to take a lead and co-ordinate contributions from smaller operators, waste collection sites, etc.

\section{Recommendation 5: Stakeholder involvement}

It has been underlined during the Workshop how important stakeholder involvement is in the setting-up of radioactive waste management strategies. In particular, it has been shown that stakeholder involvement is an integral part of the ALARA process for radioactive waste management.

It is recommended that international organizations (EC, IAEA, NEA, etc.) and EAN encourage and organise the exchange of national experiences on stakeholder engagement in the consideration of radioactive waste management options, for example through seminars or the establishment of case study documents.

Some work has already been carried out on this subject. For example, a group of radiation protection professionals from the French, Spanish and UK IRPA Associate Societies organized several workshops to share information on how stakeholder engagement has been carried out in different fields. This group has 
produced a draft document on "Guiding principles for radiation protection professionals on stakeholder engagement". This proposal was submitted to all IRPA Associate Societies during summer 2008. It is recommended that the national IRPA Associate Societies carefully examine this document from a radioactive waste management perspective.

\section{REFERENCES}

Baekelandt L., Louvat D. (2008) ALARA in the IAEA Safety Standards, which are applicable to the management of radioactive waste. In: ALARA in radioactive waste management, April 9-11, 2008, Athens (Greece)

Croüail P., Shaw P., Drouet F. (2007) "Experience and new developments in implementing ALARA in occupational, public and patient exposures", Summary and recommendation of the 10th European ALARA Network, Radioprotection 42, 227-234.

De Preter P. (2008) The Belgian experience on developing a near surface disposal facility in partnership with the local stakeholders. In: ALARA in radioactive waste management, April 9-11, 2008, Athens (Greece).

Feinhals J. (2008) Dose reduction below de minimis level? In: ALARA in radioactive waste management, April 9-11, 2008, Athens (Greece).

Gellermann R., Ettenhuber E., Flesch K., Schulz H. (2008) Optimisation in the management and disposal of NORM wastes - experiences from the $\mathrm{EAN}_{\text {NORM }}$ project. In: ALARA in radioactive waste management, April 9-11, 2008, Athens (Greece).

Hansson T., Svedberg T., Wirendal B., Lindström M., Lindberg M. (2008) Co-operation development project for new treatment of steam generators - Impact of final disposal volumes and recycling in Northern Europe. In: ALARA in radioactive waste management, April 9-11, 2008, Athens (Greece).

Hefner A., Brandl A., Beyerknecht R. (2008) Projected worker and public doses from long-term intermediate storage of radioactive waste at Nuclear Engineering Seibersdorf. In: ALARA in radioactive waste management, April 9-11, 2008, Athens (Greece).

Hoffmann D., Dreesen K., Lorenz B. (2008) Optimisation of dose exposure at cask handling for intermediate storage. In: ALARA in radioactive waste management, April 9-11, 2008, Athens (Greece).

Howett D. (2008) Review of radioactive waste in Ireland. In: ALARA in radioactive waste management, April 9-11, 2008, Athens (Greece).

Janssens A., Mundigl S., Hilden W., Bruno G. (2008) The system of radiation protection, a framework for radioactive waste management. In: ALARA in radioactive waste management, April 9-11, 2008, Athens (Greece).

Kunze V., Feinhals J. (2008), Occupational exposure in radioactive waste management in Germany. In: ALARA in radioactive waste management, April 9-11, 2008, Athens (Greece).

McDonnell C. (2008a) Assessing doses to the public from discharges of radionuclides from nonnuclear establishments in the UK. In: ALARA in radioactive waste management, April 9-11, 2008, Athens (Greece).

McDonnell C. (2008b) Incineration of low-level radioactive wastes from non-nuclear sources in the UK. In: ALARA in radioactive waste management, April 9-11, 2008, Athens (Greece).

Morley B., Butler G., Mc Glynn G. (2008) The application of ALARA in radioactive waste disposal UK perspective. In: ALARA in radioactive waste management, April 9-11, 2008, Athens (Greece). 
Savidou A., Tzika F., Hatzidakis S., Stamatelatos I.E. (2008) Application of the ALARA principle in dismantling and disposal of a research reactor primary cooling system delay tank. In: ALARA in radioactive waste management, April 9-11, 2008, Athens (Greece).

Schieber C., Schneider T., Gadbois S., Hériard-Dubreuil G. (2008) Considering the modalities of intergenerational transfer associated with radioactive waste management. In: ALARA in radioactive waste management, April 9-11, 2008, Athens (Greece).

Södermann A-L., Hellström G. (2008) Regulations on radioactive waste from practices using unsealed radioactive sources. In: ALARA in radioactive waste management, April 9-11, 2008, Athens (Greece).

Vaillant L., Drouet F. (2008) Clearance and recycling of very-low level radioactive waste: an ALARA practice? In: ALARA in radioactive waste management, April 9-11, 2008, Athens (Greece).

Vallet J., Bodenez P. (2008) For a consistent management of radioactive waste in France: the national plan for the management of radioactive material and waste. In: ALARA in radioactive waste management, April 9-11, 2008, Athens (Greece).

Vogiatzi S., Carinou E., Potiriadis C, Hourdakis C-J., Dimitriou P., Kamenopoulou V. (2008) Doses to sewage workers due to ${ }^{131}$ I waste used for therapeutic purposes. In: ALARA in radioactive waste management, April 9-11, 2008, Athens (Greece).

Warren L., Morley B. (2008) Stakeholder involvement in radioactive waste management in the UK. In: ALARA in radioactive waste management, April 9-11, 2008, Athens (Greece). 